\title{
Trade-off between India's Trade Promotion and its Environmental Sustainability
}

\author{
Dr. Manasi Gore ${ }^{1}$, Dr. Meenal Annachhatre ${ }^{2}$
}

\begin{abstract}
The concept of sustainable development involves three components namely economic, social and environmental. In a developing economy like that of India, the economic sustainability demands higher growth of key economic indicators such as National income, employment generation, production, consumption and even the foreign trade. The growth of foreign trade and that of the exports are very critical for the foreign exchange reserves essential to pay for the imports in India. Trade as an engine of the economic growth thus fulfils the essential implication for economic sustainability. But in achieving this growth, economy's environmental sustainability is at stake. This is because, the top export products of India still comprise of petroleum products (18\%), agricultural products $(12 \%)$, textiles and yarns together at $11 \%$ and chemicals $(10 \%)$. All these exports in their production have immensely contributed towards environmental pollution in one way or the other. Mining for gold, silver and diamonds resulted in water pollution, Green House Gas emission, and soil erosion. Petroleum refineries are a major source of hazardous and toxic air pollutants such as particulate matter (PM).

Though India's contribution to the total world trade is yet negligible, while promoting the major exports as mentioned above the natural resources are exploited too much and thus create a threat to India's environmental sustainability. This paper therefore advocates the need for the Green products' exports to make India's growth story even environmentally sustainable.
\end{abstract}

Keywords: Sustainable development, Green products, Exports, Imports, Environmental Pollution

\section{Introduction}

Trade plays an important role in accelerating the growth of the economy. To be specific in case of developing and emerging countries like India trade has manifold significance. Over the past two decades trade has been looked upon as an engine of economic growth specifically to the developing countries. The theory of trade is founded on the premise that there exists a stable, mechanical relationship between economic growth in developed countries and export growth in developing countries. But then how far is this export growth or economic development going to be sustainable is a critical issue.

The process of integration of the world economies after 1990 enlarged the spectrum of trade possibilities across the developed and developing economies through the trade openness. With trade a country gets specialized and efficient production processes, market place and more consumption options. Countries can also bank on the rising foreign exchange reserves and other inflows of foreign investments and technology. Another valid argument for trade openness is pointing towards the scarce resources. So

$\mid{ }^{1}$ Assistant Professor, Department of Economics, Savitribai Phule Pune University, Pune, Maharashtra, India.

${ }^{2}$ Assistant Professor, Department of Economics, Savitribai Phule Pune University, Pune, Maharashtra, India. 
what is not available at your end can be easily imported and offered for in-house production of goods. This back and forth activity increased further when developing countries witnessed heavy growth of population. This further puts a pressure on their natural resources to meet the growing and diversifying needs of consumption. Their rising dependency on imports increased the demand for foreign exchange and export is the only solution to earn the big chunk of foreign exchange through which the growing imports can sustain.

The above argument for trade looks perfect and very convincing but the concern here is of the pressure that we are putting on the existing environmental resources and disturbing the environmental balance. World trade expansion has raised the serious issue of the relationship between trade activity and the depletion of natural/environmental resources. Is trade bad or good for the environment? Answer to this question is not completely black or white. Openness to trade might encourage some countries to specialize in dirtier activities and to export their products to others which would have heavy environmental degradation cost to its own country and would be spreading the pollution across the globe. Under the well known "Pollution Havens" hypothesis, globalization has its primary effect on the distribution of pollution across countries, rather than on the overall average. ${ }^{1}$

\section{Trade as an Engine of Growth}

Exposure to international trade can also make the domestic economy more specialized and efficient one. Other peripheral sectors to trade activities also tend to become more efficient over a course of time. For example, forward and backward linkages of two sectors like Industry and Agriculture: if Industry is into exports of different manufactured goods and agriculture is providing it the required raw material then this backward linkage will spread the specialization impact over the agricultural activities as well and will make them more efficient in their processes. And in case of a country like India, these forward and backward linkages can generate positive as well as negative externalities.

The export sector is generally the leading sector that propels the economies into rapid growth and development. The stimulus provided by the rapidly expanding exports spreads to the rest of the economy through the familiar Accelerator-Multiplier Process. The developing nations are richly endowed with natural resources such as fertile arable land, forests, and mineral deposits. So the nations can take advantage of the resource availability and get into extensive trade promotion which may prove as an engine of growth for developing economies like India. Even low cost imports help them to speed up the process of economic convergence.

\section{Environment and Sustainable Development}

It is very well proved that trade accelerates the economic growth but at the same time it raises the issue of the environmental degradation and pollution which is the blazing problem nowadays for every economy specially the developing ones like that of

1Jeffrey Frankel, 2008,'Environmental Effects of International Trade', Expert Report Number 31 to Sweden's Globalization Council 
India. For this, at first we will look at the concept of Sustainable Development (SD) which will conduct itself as the solution to the problem restated above. According to 'Our Common Future' known as the Brundtland Report by World Commission on Environment and Development (WCED 1986), "Sustainable development is development that meets the needs of the present, without compromising the ability of future generations to meet their own needs".

The concept of SD can be interpreted in many different ways, but at its core is an approach to development that looks to balance different, and often competing, needs against an awareness of the environmental, social and economic limitations we face as a society. The longer we pursue unsustainable development, the more frequent and severe its consequences are likely to become, which is why we need to take action now. The key principle of sustainable development underlying all others is the integration of environmental, social, and economic concerns into all aspects of decision making. The recently developed 17 Sustainable Development Goals (SDGs) to be achieved by 2030, underlined the significance and the need for the SD. Sustainability leads towards that growth which will keep the environment intact and at the same time will increase the welfare of the people.

\section{Pollution Haven Hypothesis}

The pollution haven hypothesis, or pollution haven effect, is the idea that polluting industries will relocate to jurisdictions with less stringent environmental regulations. Empirical studies of the phenomenon have been hampered by the difficulty of measuring regulatory stringency and by the fact that stringency and pollution are determined simultaneously. The pollution haven hypothesis posits that jurisdictions with weak environmental regulations - 'pollution havens' - will attract polluting industries relocating from those jurisdictions with more stringent locales. The pollution haven hypothesis thus explains the effects of international trade on environment such as production of dirty goods (pollutants), which is a negative externality that further leads to a reverse causation. This is because, the lax environmental regulations (generally in case of developing economies) enable the industrial producers to charge the price less than the social cost of production, which is inflicted upon the society in terms of the health hazards. In this case the private costs of production are less than the social cost of production. This under estimation of costs may provide for a competitive advantage for a country in the international market, but "It is a perverse, rather than genuine comparative advantage"2

\section{Trends in Indian Exports Trade Since 1990}

During the last 25 years, India's exports have increased more than 17 times, from US\$ 18.1 billion in 1990- 91 to US\$ 309 billion in 2014-15, and India's imports have increased 19 times, from US\$23.5 billion in 1990-91 to US\$ 447 billion in 2014-15. India's share in global exports has moved up from mere 0.6 percent in early nineties to almost 1.7 percent currently. Likewise, India's share in global imports has increased from around 0.6 percent during early nineties to 2.4 percent currently. In the first decade of

2TRADE AND ENVIRONMENT, a book by RAJAT ACHARYYA 
this period (1990-91 to 1999-2000), India's exports grew at a compound annual growth rate of 8.1 percent and imports at 8.7 percent. The real surge was witnessed in the next decade (2000-01 to 2009-10), when exports grew at 16.8 percent and imports at 21.5 percent annually. This trend continued until 2011-12, after which there has been a steady decline in trade owing to global slowdown. In 2014-15, exports dipped by 1.8 percent while imports dipped by 0.4 percent. For the first 11 months in financial year 2015-16, exports as well as imports have seen a sharp decline. While exports are lower by 16.7 percent year over year, imports have declined by 14.8 percent year over year. ${ }^{3}$

\section{Indian Exports of Principal Commodities}

Plantation Crops : Export of Plantation crops during 2013-14, decreased by 8.17 per cent in US \$ terms. Export of Coffee registered a negative growth of 7.81 per cent and export of Tea also decreased by 8.54 per cent. These exports of plantation crops fall into the category of green exports.

Agriculture and Allied Products : Agriculture and Allied Products as a group include Cereals, Pulses, Tobacco, Spices, Nuts and Seeds, Oil Meals, Guar gum Meal, Castor Oil, Shellac, Sugar \& Molasses, Processed Food, Meat \& Meat Products, etc. During 2013-14, exports of commodities under this group registered a growth of 0.81 percent.

Ores and Minerals: Exports of Ores and Minerals were estimated at US \$ 5,604.22 million during 2013-14 registering a negative growth of 0.48 per cent over 201213. Sub groups viz. Iron Ore, and mica have recorded a negative growth of 5.45 per cent and 0.57 percent respectively. These exports would fall into a category of dirty exports.

Leather and Leather Manufactures : Export of Leather and Leather Manufactures recorded a growth of 16.49 per cent during 2013-14 and Leather Footwear registered a growth of 20.35 per cent. Leather tanning is a chemical- heavy process leading to harmful toxic waste. Leather garments and products have heavy demand from all developed countries and to satisfy this demand the toxic toll leather tanning takes on environment and human health, has been relegated to impoverished nations and India is a part of it. When it comes to leather stitching and packing, this particular industry falls into a green industry category.

Gems and Jewellery: The export of Gems and Jewelry showed a negative growth of 5.18 per cent.

Chemicals and related Products : During the period 2013-14, the exports of Chemicals and Related Products registered a growth of 5.42 per cent while Rubber, Glass \& Other Products, Basic Chemicals, Pharmaceuticals \& Cosmetics, Plastic and linoleum and residual chemicals \& allied products have registered a positive growth.

Engineering Goods : Items under this group consist of Machinery, Iron \& Steel and Other Engineering items. Export from this sector registered a positive growth of 8.5 per cent..

Electronic Goods : During the period 2013-14, exports of Electronic Goods as a group registered a negative growth of 8.91 per cent. 
Textiles : During this period Textiles exports recorded a positive growth of 15.24 per cent along with Readymade Garments, Cotton yarn/Fabrics., Manmade Textiles \& Coir and coir manufactures registered a positive growth of 15.53 per cent, 18.11 per cent, 12.85 per cent and 16.89 per cent respectively.

Handicrafts and Carpets : Exports of Handicrafts registered a positive growth of 36.01 per cent.

Petroleum Products :Export of Petroleum Products increased to US \$ 62,685.29 million during 2013-14, as compared with US \$ 60,859.81 million in 2012-13 recording a positive growth of 3 per cent.

\section{Imports of India and Major Trends}

The following product groups signify the highest dollar value in India's import purchases during 2018. Also exhibited is the percentage share of each product category which is exemplified in terms of overall imports into India. .Mineral fuels including petroleum and oil: US $\$ 168.6$ billion (33.2\% of total imports); Gems, precious metals: $\$ 65$ billion (12.8\%); Electrical machinery, equipment: \$52.4 billion (10.3\%); Machinery including computers: $\$ 43.2$ billion (8.5\%); Organic chemicals: $\$ 22.6$ billion (4.4\%); Plastics, plastic articles: $\$ 15.2$ billion (3\%); Iron, steel: $\$ 12$ billion (2.4\%); Animal/vegetable fats, oils, waxes: $\$ 10.2$ billion (2\%); Optical, technical, medical apparatus: $\$ 9.5$ billion (1.9\%); Inorganic chemicals: $\$ 7.3$ billion (1.4\%).

India's top 10 imports accounted for four-fifths $(80 \%)$ of the overall value of its product purchases from other countries. Imported mineral fuels including oil had the fastestgrowing increase in value among India's top 10 import categories, up 37\% year over year. In second place for expanding import purchases was the inorganic chemicals category via a $29.8 \%$ improvement, trailed by the $25.6 \%$ increase for organic chemicals and the $20.1 \%$ gain for machinery including computers. The two declining categories for India's imports were animal and vegetable fats, oils and waxes (down -14.4\%) and gems and precious metals (down -12.6\%).

\section{Environmental Performance Index of India}

India has been ranked 177 among 180 countries in the Environmental Performance Index (EPI), $2018{ }^{4}$. This report was released on 23 January, 2018 on the side-lines of World Economic Forum. Environmental Performance Index (EPI) is calculated on the basis of data gathered from 24 individual metrics of environmental performance. These 24 individual metrics are then aggregated into a hierarchy that begins with 10 major environmental issues categories.
1. Air Quality
2. Water \& Sanitation
3. Heavy Metals (lead exposure)
4. Biodiversity \& Habitat
5. $\quad$ Forests (tree cover loss)

4 This index has been developed by Yale University and Columbia University in collaboration with the World Economic Forum and the Joint Research Centre of the European Commission. 
6. Fisheries

7. Climate \& Energy (CO2, Methane and Black Carbon Emissions)

8. $\quad$ Air Pollution

9. Water resources (wastewater treatment)

10. Agriculture (sustainable practice)

The report has ranked India as fourth worst country worldwide in curbing environmental pollution. India has slipped from 141st position in 2016 report. The low ranking of emerging economies including China (120) and India (177) indicates the strain, population pressures and rapid economic growth impose on the environment. As per the report, substantial populations still suffer from poor air quality, most notably in India, China, and Pakistan (169). This Report also notes that the low scores on the EPI are indicative of the need for national sustainability efforts on a number of fronts, especially cleaning up air quality, protecting biodiversity and reducing GHG emissions.

\section{Trade off between Exports and Environment}

The correlation between exports of India and the $\mathrm{CO}_{2}$ emissions after running a correlation analysis is 0.96 . It is a positive correlation which means as the trade is rising the pollution levels are also on the rise which is a bad sign for Indian economy from environmental point of view. This positive correlation between major pollutant $\mathrm{CO}_{2}$ and the exports of India shows that the trade of India is not environmentally sustainable and the nation needs to change its trade composition from dirty and polluting exports products to green products that are exportable and should strive to make the trade of India as environmentally sustainable one. This can be done through promoting some green strategies for production and to substitute the dirty exports with green export products. This section is seen further in this paper.

Table 1 Exports, GDP and $\mathrm{CO}_{2}$ Emissions Statistics

\begin{tabular}{|c|c|c|c|c|c|}
\hline Year & $\begin{array}{l}\text { Total exports } \\
\text { (Rs. Billion) }\end{array}$ & $\begin{array}{lr}\begin{array}{l}\text { Total } \\
\text { emissions } \\
\text { tonnes })\end{array} & \begin{array}{r}\mathrm{CO} 2 \\
(\mathrm{~kg}\end{array} \\
\end{array}$ & $\begin{array}{l}\text { Total GDP } \\
\text { (Rs billion) }\end{array}$ & $\begin{array}{l}\text { Export to GDP } \\
\text { ratio }\end{array}$ & $\begin{array}{l}\text { Export of principal } \\
\text { commodities } \\
\text { (Rs. Billion) }\end{array}$ \\
\hline $2000-01$ & 2035.71 & 1031853.463 & 21774.13 & 0.1313 & 1979.56 \\
\hline $2001-02$ & 2090.18 & 1041152.975 & 23558.45 & 0.1269 & 2034.18 \\
\hline $2002-03$ & 2551.37 & 1054258.833 & 25363.27 & 0.1441 & 2493.67 \\
\hline 2003-04 & 2933.67 & 1099597.621 & 28415.03 & 0.151 & 2847.27 \\
\hline $2004-05$ & 3753.4 & 1154320.262 & 32422.09 & 0.1805 & 3651.74 \\
\hline $2005-06$ & 4564.18 & 1222563.132 & 36933.69 & 0.1982 & 4453.02 \\
\hline $2006-07$ & 5717.79 & 1303717.509 & 42947.06 & 0.2166 & 5578.59 \\
\hline $2007-08$ & 6558.64 & 1407607.286 & 49870.9 & 0.2101 & 6397.17 \\
\hline 2008-09 & 8407.55 & 1668397.567 & 56300.63 & 0.2427 & 8063.26 \\
\hline $2009-10$ & 8455.34 & 1738645.711 & 64778.27 & 0.2062 & 8045.89 \\
\hline $2010-11$ & 11429.22 & 1719690.988 & 77841.15 & 0.2259 & 10582.89 \\
\hline $2011-12$ & 14659.59 & 1841776.419 & 90097.22 & 0.2454 & 13765.93 \\
\hline $2012-13$ & 16343.18 & 2018503.817 & 101132.81 & 0.2453 & 15795.69 \\
\hline
\end{tabular}




\begin{tabular}{|l|l|l|l|l|l|}
\hline $2013-14$ & 19050.11 & 2034752.294 & 113550.73 & 0.2541 & 18449.19 \\
\hline $2014-15$ & 18964.45 & 2238377.137 & 125412.08 & 0.2297 & 17791.85 \\
\hline
\end{tabular}

Source: RBI and World bank data

Table 2 Correlation Values

\begin{tabular}{|l|l|l|l|l|l|}
\hline & $\begin{array}{l}\text { Total } \\
\text { exports } \\
\text { (Rs. } \\
\text { Billion) }\end{array}$ & $\begin{array}{l}\text { Total } \\
\text { CO2 } \\
\text { tonnes) }\end{array}$ & $\begin{array}{l}\text { Total } \\
\text { GDP(Rsbillion) }\end{array}$ & $\begin{array}{l}\text { Export to } \\
\text { GDP } \\
\text { Ratio }\end{array}$ & $\begin{array}{l}\text { Export } \\
\text { principal } \\
\text { commodities } \\
\text { Billion) }\end{array}$ \\
\hline Total exports (Rs. Billion) & 1 & & & & \\
\hline $\begin{array}{l}\text { Total CO2 emissions (kg } \\
\text { tonnes) }\end{array}$ & 0.97 & 1 & 1 & 0.91 & \\
\hline Total GDP (Rs billion) & 0.99 & 0.98 & 0.96 & 0.83 & 1 \\
\hline $\begin{array}{l}\text { Export to GDP ratio } \\
\text { Export of principal } \\
\text { commodities ( Rs. } \\
\text { Billion) }\end{array}$ & 0.93 & 0.96 & & & \\
\hline
\end{tabular}

We can see that there is a positive correlation that is $\mathbf{r}=\mathbf{0 . 9 6}$ (' $r$ ' is the denotation correlation coefficient), between total $\mathrm{CO}_{2}$ emissions and export of principle commodities of India. This means as the exports of principle commodities are increasing, the total $\mathrm{CO}_{2}$ emissions are also showing a rising trend. We can also see that there is positive correlation between the export to GDP ratio and export of principle commodities which is $\mathbf{0 . 8 3}$. There is also positive correlation between $\mathrm{CO}_{2}$ emissions and Total exports of India that is 0.97 . Hence, all these positive correlations are pointing towards one thing that Indian exports are not environmentally sustainable as they are contributing to more $\mathrm{CO}_{2}$ emissions throughout the period of analysis.

Now to check the reliability and significance of the value of ' $r=0.96$ ', between $\mathrm{CO}_{2}$ emissions and exports of principal commodities, we calculated the probable error of ' $r$ '. P.E. $=0.6745 \times($ S.E. $)$ standard error of ' $r$ ' $=0.0136537$. If the value of ' $r$ ' is greater than $6 \times$ P.E (that is six times of probable error) then our ' $\mathrm{r}$ ' will be highly significant.

$6 \times$ P.E $=6 \times 0.0136537=0.01892$, which is less than our value of ' $r$ '. $\mathrm{r}=0.96>0.01892$

The above equation proves that our ' $r$ ' value is greater than the six times of probable error (' $r$ '). Hence the correlation between $\mathrm{CO}_{2}$ emissions and the exports of principal commodities is highly significant and reliable.

All the above analysis is done till 2014 due to the data availability mainly about the carbon emissions of India. Therefore the further analysis is done by taking the projected figures of carbon emissions of India. The data is as follows. 


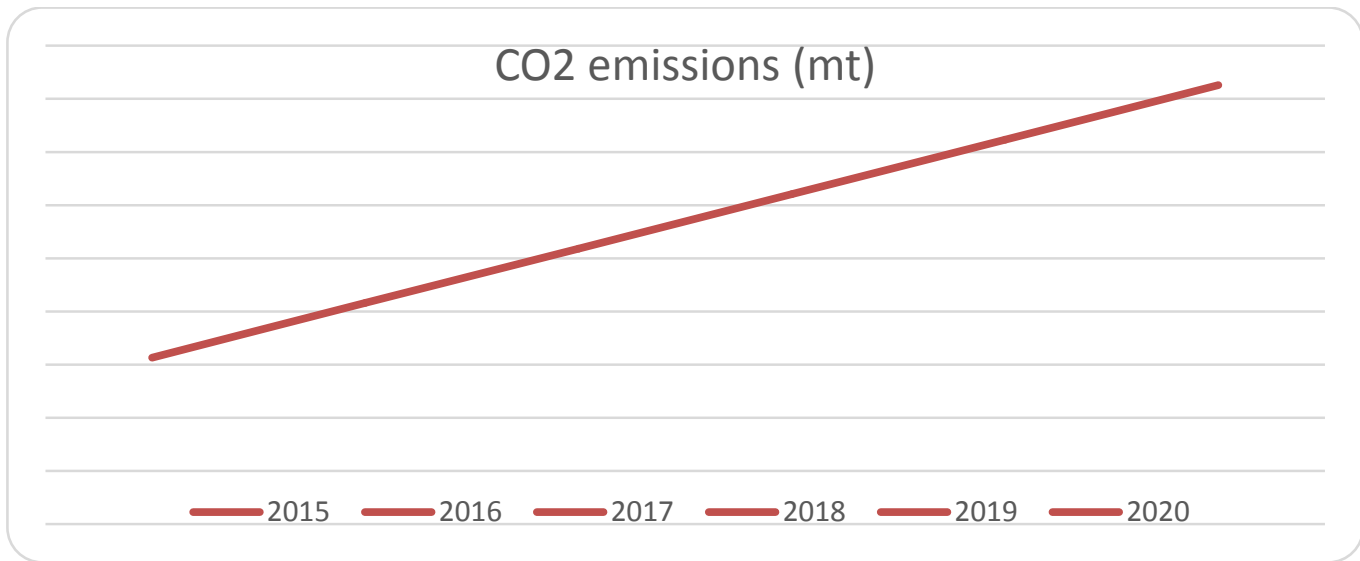

Graph 1 Projected Emissions of $\mathrm{CO}_{2}$

Source: Climate Action Tracker (CAT)

Graph 1 is showing the projection for 5 years from 2015 to 2020. The predictions estimated by CAT report would be helpful to understand the future trends of carbon emissions. In the above graph we can also see that the persistent increase in carbon emissions and the upward sloping line is showing that the carbon emission of India would increase by 500 metric tons till 2020 .

With reference to Exports, GDP and $\mathrm{CO}_{2}$ Emissions Statistics, we observed three distinct phases of trends so the further analysis is done with these phases. It can be seen clearly from following graphs.

\section{Export of principal commodities ( Rs. Billion)}

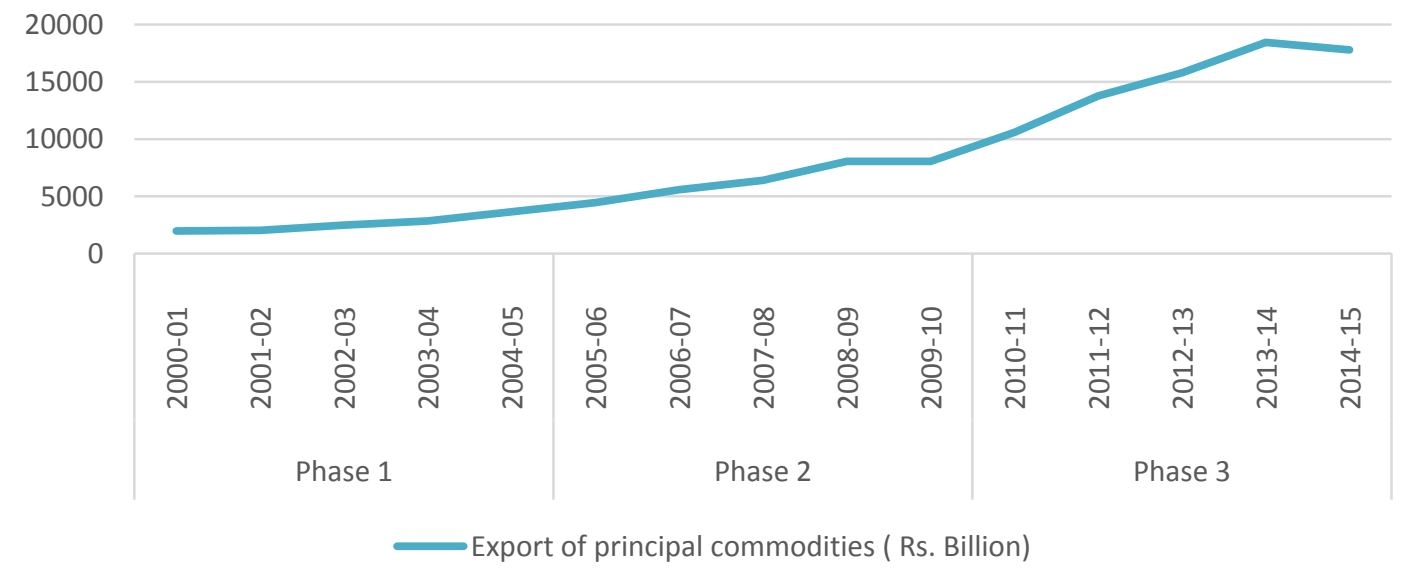

Graph 2 Phase Analysis of the Variables Considered Under study

In Graph 2 we can see that it is divided into three phases 2000 to 2004, 2005 to 2009, 2010 to 2014 respectively. In each phase the exports of principal commodities are showing a rising trend 


\section{Total exports (Rs. Billion)}

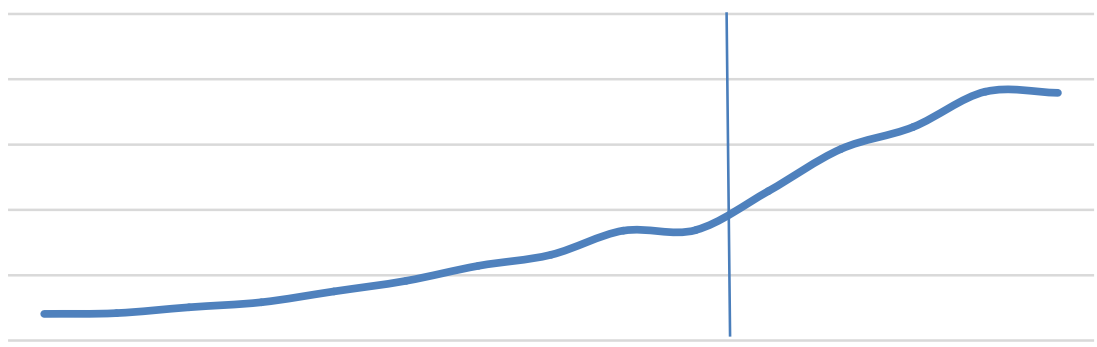

Graph 3 Phase Analysis of the Variables Considered Under study

Graph No.3 is the representation of total exports of commodities. There are three phases of this graph which ranges between 2001 to 2005, 2006 to 2010 and 2011 to 2014 respectively. All three phases are showing the increasing trend of export of principle commodities.

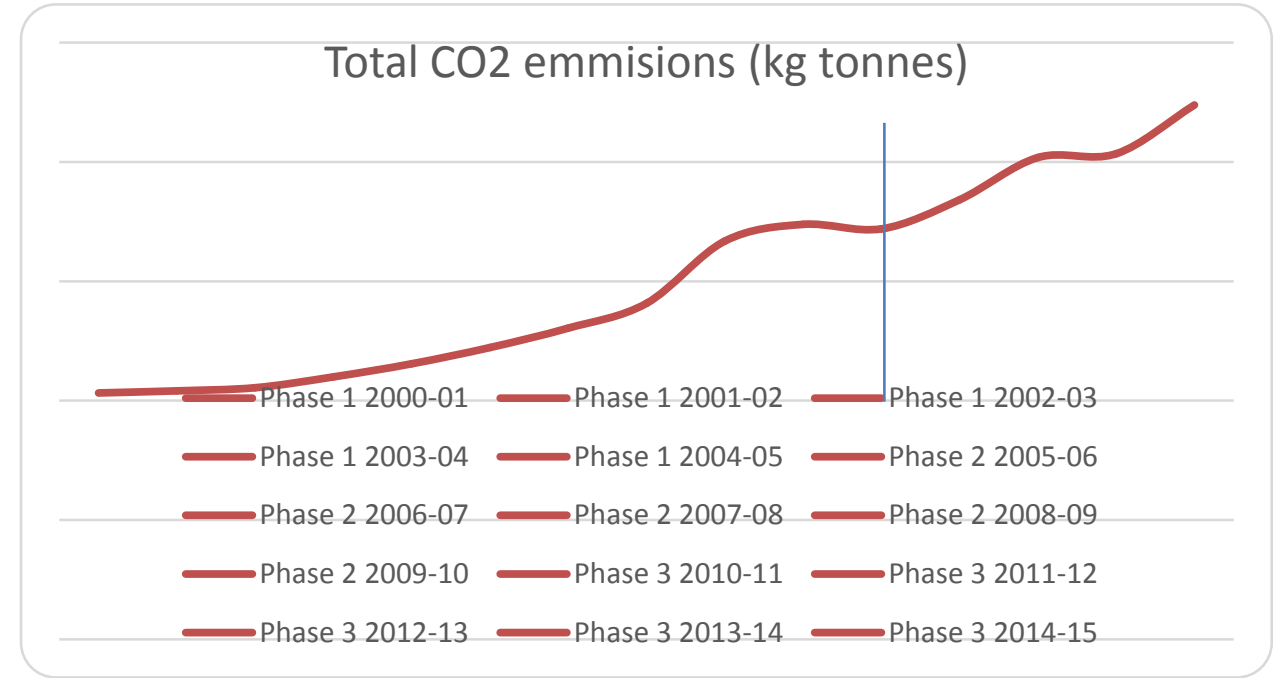

\section{Graph 4 Phase Analysis of the Variables Considered Under study}

Graph No. 4 is depicting the $\mathrm{CO}_{2}$ emissions in three phases, where the first phase is from 2000 to 2004 which is showing a constancy in carbon emissions growth. Second phase shows mild and then a sudden spurt in the carbon emissions. Third phase too shows the same trend. 


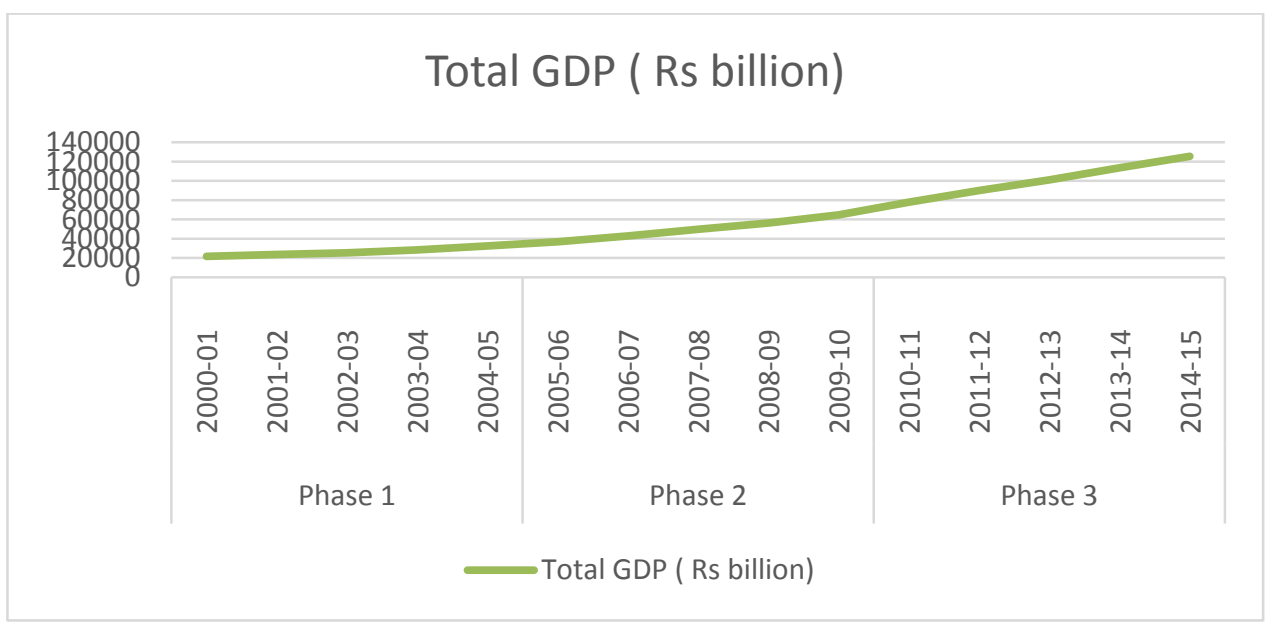

Graph 5 Phase Analysis of the Variables Considered Under study

Graph No. 5 is showing the trend of total GDP growth of India. Phase 1 is showing the slow growth of GDP compare two other two phases.

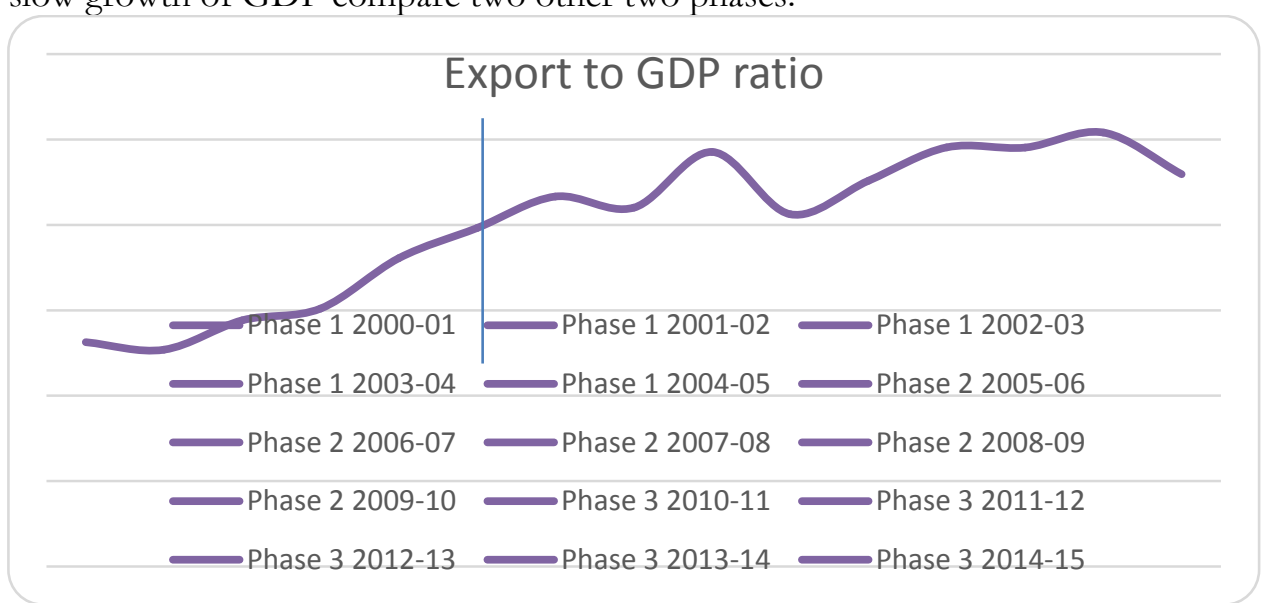

\section{Graph 6 Phase Analysis of the Variables Considered Under study}

Graph no. 6 is showing the Export to GDP ratio in case of India, in three phases. In the first phase the ratio is rising. In the second phase there is further increase in the ratio. In the year 2008 the ratio is at its peak due to the financial crisis of 2007-08.

\section{Is India's trade environmentally sustainable?}

The top exports have led to a great growth in India but the production of these goods has immensely contributed towards environmental pollution in one way or the other. Mining results in water pollution, greenhouse gas emission, and soil erosion. Petroleum refineries are a major source of hazardous and toxic air pollutants like particulate matter (PM), nitrogen oxides (NOx) and so on. So by looking at the extent of 
pollution caused by our exports we can state that our export growth is not environmentally sustainable.

\section{Categorization of Indian Export Industries}

The Indian Ministry of Environment, Forest and Climate Change (MoEFCC) has developed the criteria of categorization of industrial sectors based on the Pollution Index ${ }^{5}$ which is a function of the emissions (air pollutants), effluents (water pollutants), hazardous wastes generated and consumption of resources. Here we offer some representative categorization of industries.

Table 3 Categorization of Industries as per Pollution Index by MoEFCC: A Sample

\begin{tabular}{|c|c|c|c|}
\hline $\begin{array}{l}\text { Red Industries } \\
\text { PI Value greater than } \\
60\end{array}$ & $\begin{array}{l}\text { Orange Industries } \\
\text { PI Value between } 30 \\
\text { and 59 }\end{array}$ & $\begin{array}{l}\text { Green Industries } \\
\text { PI Value between } 15 \\
\text { and } 29\end{array}$ & $\begin{array}{l}\text { White Industries } \text { PI } \\
\text { Value less than } 15\end{array}$ \\
\hline hazardous chemicals & Cashew nut processing & Ayurvedic medicines & $\begin{array}{l}\text { Bio fertilizer /bio- } \\
\text { pesticides }\end{array}$ \\
\hline Milk a & ultry feed & Spic & $\begin{array}{l}\text { Cotton and woollen } \\
\text { hosiers }\end{array}$ \\
\hline Petro & $\begin{array}{l}\text { Fish processing and } \\
\text { packing }\end{array}$ & Spic & $\begin{array}{l}\text { Leather cutting and } \\
\text { stitching }\end{array}$ \\
\hline Pharn & $\begin{array}{l}\text { Food and } \\
\text { processing }\end{array}$ & Grains / te & $\begin{array}{l}\text { Coir items from coconut } \\
\text { husks }\end{array}$ \\
\hline
\end{tabular}

\section{Major Findings and Implications}

- There is a positive correlation of 0.96 between total $\mathrm{CO}_{2}$ emissions and export of principle commodities of India.

- The Export to GDP Ratio in India has increased since 2000a from $12.69 \%$ to nearly $25 \%$. Obviously there is positive correlation between the export to GDP ratio and export of principle commodities which is 0.83 .

- There is also positive correlation between $\mathrm{CO}_{2}$ emissions and Total exports of India that is 0.97 .

- As the percentage of the exports in GDP is increasing, the $\mathrm{CO}_{2}$ emissions of the nation will also have an increment in it.

- This means that export industries of India are contributing to pollution and environmental degradation

- The existing composition of Indian Exports needs a substitution in terms of more Green Exports and their promotion.

- $\quad$ There is a need to think a Trade off between Indian exports and the Sustainable development through Green Products.

\section{Scope for Major Green and Sustainable Business Opportunities through Exports of India}

- Landscaping professionals can now focus on reducing pesticides and chemical fertilizer while returning valuable organic material to the soil through composting and

\footnotetext{
5 The Pollution Index PI of any industrial sector is a number from 0 to 100 and the increasing value of PI denotes the increasing degree of pollution load from the industrial sector.
} 
mulching. Demand for organic and residue free products is increasing worldwide. India being agriculture dominated economy can shifts its crop pattern more inclined towards the organic food. For example, Sikkim state of India has already shown a positive hope in this sector by becoming the $100 \%$ organic farming preferred state. By promoting proorganic policies like subsidies for export, well-structured markets and promising good returns to farmers. More production of organic commodities will automatically lead to their export promotion

- $\quad$ Energy Auditing can help home and business owners reduce monthly bills and lower reliance on the traditional energy grid. Increasingly in demand, efficiency experts help modernize and green existing structures. Services sectors reach and area is widening day by day and when world is on the verge of facing biggest issue of global warming India can lead in this sector by providing consultancy services to other countries we can call it green consultancy.

- $\quad$ Cleaning Services provide traditional services with eco-friendly products and processes. Opportunities exist for pet cleaners, maids, car washes and more. For example BVG India Ltd. is the housekeeping and sanitary services providing company which offers its services across the India and in foreign countries also. More start-ups can be settled up in this sector also

- Solar Installations are growing as panels are becoming smaller and more efficient. From rooftop installs to small data transmitters to decorative displays, solar energy use is one the rise. Government of India has set up a target for reaching to the goal of achieving solar power generation capacity of $100 \mathrm{GW}$ by 2022. Once economies of scale start functioning, India can export its solar energy. We have set a target for reaching the goal of achieving solar power generation capacity of $100 \mathrm{GW}$ by 2022 . Storing of solar energy now being possible, India can export its solar energy to neighbour countries and can also export the solar panels and its technology. Considering heavy pressure on POL imports, the progress in solar energy would substitute our POL imports and can make our trade more sustainable. Prime Minster Modi's International Solar Alliance with France can prove to be the game changer in this sector.

- Dr R Vasudevan a chemistry professor and dean at the Thiagaraiyar college of Engineering in Madurai has developed the very successful method of building roads from plastic waste which is considered as the biggest harm for ecology. The best part of this programme is that the cost of building is lower than building the road from tar and the average life is also more than that of other roads. Indian government can seriously think about exporting this technology to other developing countries where infrastructure building always remains on everyone's agenda.

- $\quad$ Paper and Carpets made from Banana fibre and wastes, Stone papers along with Khadi and village industry products are the Green products and on the basis of Comparative advantage, India can develop these exports largely.

- Technical expertise and Consultancies about Eco-friendly Low Cost Houses (IIT Madras Innovation), Green buildings

- Green marketing, auditing and accounting services, Green Energy and related Consultancies under the vibrant services exports also are lucrative 
- Even the Hotel industry in India contributes to Export earnings today. The restaurants using fresh organic and green products can generate environmental efficiencies for Health conscious foreign tourists in India.

To conclude, India's contribution to world trade though is marginal it has to be made more sustainable environmentally. It is a crucial challenge for the government to strike a balance between the growth and export trade on sustainable grounds. Rising awareness about the climate change and environmental degradation across the World will surely give the positive response to the promotion of Green products' export from India. Green products' exports can be the probable solution to a tradeoff between the exports and SD in India.

\section{References:}

Climate Action Tracker . (2018). Retrieved from climateactiontracker.org: https://climateactiontracker.org/countries/india/

CO2 Emissions Statistics. (2016). Retrieved from www.iea.org: http://data.iea.org/payment/products/115co2-emissions-from-fuel-combustion-2018-edition-coming-soon.aspx

Communicating Green Products to Consumers in India to promote Sustainable Consumption and Production. (2014). 60.

ECONOMICS, ECOLOGY AND THE ENVIRONMENT . (n.d.). Retrieved from https://ageconsearch.umn.edu/bitstream/48005/2/WP42.pdf

Industrial Pollution in Indian Industries:. (n.d.). Retrieved from http://www.krishisanskriti.org/vol_image/08Jul2015

International Trade and Environmental Development: A View from India. (n.d.). Retrieved from https: / www.repository.law.indiana.edu/cgi/viewcontent.cgi?article $=1014 \&$ context $=$ ijgls

Ministry of Environment, Forest and Climate Change. . (2016). Retrieved from http://pib.nic.in/newsite/PrintRelease.aspx?relid=137373

Statistics Related to. (2015). Retrieved from www.mospi.gov.in: http://www.mospi.gov.in/sites/default/files/publication_reports/climateChangeStat2015.pdf

Trends in India's Foreign Trade. (2013). Retrieved from http://commerce.gov.in: http://commerce.gov.in/pdf_download/5.Trends\%20in\%20India's\%20Foreign\%20Trade.pdf

workman, D. (2019). World's top exports. Retrieved from www. worldtopexports.com: http://www.worldstopexports.com/indias-top-10-imports/

Mangalagouri Avali, July 2014,' An analysis of structural chnages in Agri-Exports-Imports Trade in India,' Dept. of Agribusiness Management University of Agricultural Sciences, Dharwad. 